\title{
Massimo Blanco, Leggere Baudelaire
}

\section{Ida Merello}

\section{(2) OpenEdition}

\section{Journals}

\section{Edizione digitale}

URL: http://journals.openedition.org/studifrancesi/2235

DOI: 10.4000/studifrancesi.2235

ISSN: 2427-5856

\section{Editore}

Rosenberg \& Sellier

\section{Edizione cartacea}

Data di pubblicazione: 1 aprile 2014

Paginazione: 174

ISSN: 0039-2944

\section{Notizia bibliografica digitale}

Ida Merello, « Massimo Blanco, Leggere Baudelaire », Studi Francesi [Online], 172 (LVIII | I) | 2014, online dal 01 avril 2014, consultato il 18 septembre 2020. URL : http://journals.openedition.org/ studifrancesi/2235; DOI : https://doi.org/10.4000/studifrancesi.2235

\section{Questo documento è stato generato automaticamente il 18 settembre 2020.}

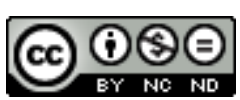

Studi Francesi è distribuita con Licenza Creative Commons Attribuzione - Non commerciale - Non opere derivate 4.0 Internazionale. 


\title{
Massimo Blanco, Leggere Baudelaire
}

\author{
Ida Merello
}

\section{NOTIZIA}

MASSIMO BLANCO, Leggere Baudelaire, Roma, Carocci, 2013, pp. 94.

1 Il volumetto si propone come strumento di supporto per gli studenti: l'A. procede in maniera analitica, dai cenni biografici, con gli anni di formazione e le prime influenze letterarie, fino all'analisi dell'opera, con la suddivisione in capitoli su Baudelaire critico, le Fleurs du Mal, e le altre opere. Il volume offre informazioni utili, e qualche affermazione un po' troppo apodittica, nel momento in cui tenta definizioni univoche della complessità del pensiero baudelairiano. 